\title{
STRATEGIES FOR SCALING UP SOCIAL BUSINESS IMPACT ON SUSTAINABLE LIVING: A CASE STUDY ON SBLIF \\ Farhana Ferdousi $^{1 *}$, Parveen Mahmud ${ }^{2}$
}

\author{
${ }^{1 *}$ Southeast Business School, Southeast University, Dhaka, Bangladesh; ${ }^{2}$ Grameen Telecom Trust, Dhaka, Bangladesh. \\ Email: "dfferdousi@gmail.com
}

Article History: Received on $31^{\text {st }}$ October 2020, Revised on $17^{\text {th }}$ October 2020, Published on $25^{\text {th }}$ November 2020

\begin{abstract}
Purpose of the study: The objective of the study was to investigate scaling up strategies of social business projects in order to create sustainable livelihood among the beneficiaries.
\end{abstract}

Methodology: Qualitative research design was found suitable for this study. A case study method was applied through pursuing face-to-face interviews. Seven social business learning and innovation (SBLIF) projects of Grameen Telecom Trust (GTT) have been selected purposively for the analysis.

Main Findings: Findings get evidence of organic growth, collaboration, and dissemination strategies to create impact over sustainable living. Through organic growth, social businesses were generating employment opportunities for communities' people and enhancing their livelihoods. Collaboration with GTT provided social businesses with access to financial and network resources which helped them to serve disadvantaged, rural, endogenous, and climate-vulnerable people. Disseminations of livelihood strategies helped producers and inhabitants to achieve sustainability in many areas.

Social Implications/Applications: Social business, a social purpose-driven business, is attracting worldwide attention for its impact on sustainable living through reducing poverty, inequality, unemployment, and negative environmental impacts. But to create more impact on sustainable livelihood, scaling up the social business organization itself is mandatory. This study could be a guide for social business entrepreneurs and policymakers to advance sustainable livelihoods.

Originality/Novelty of the Study: Most of the research uses the term social business as a wider concept which mostly relies on philanthropic-funds. This study focuses on a unique type of social business organizations who are not expected to rely on such philanthropic-funds rather have to cover operating costs which make these businesses a new kind of learning for all social entrepreneurs.

Keywords: Scaling Strategy, Social Business, SBLIF, Grameen Telecom Trust, Sustainable Living.

\section{INTRODUCTION}

Social enterprises are broadly defined as organisations pursuing a social mission, i.e., reducing unemployment, malnutrition, poverty, environmental pollution, etc. through their economic activity (Ferdousi, 2017; Borzaga and Defourny, 2001; Defourny and Nyssens, 2006). This pioneering business model, due to its significance in addressing social and environmental problems through innovative solutions, is receiving increasing attention day by day from the whole world. It is often argued that social enterprises are ventures that are created by social entrepreneurs (Haugh, 2005). However, Nobel Laureate Professor Yunus identified social enterprises as ventures that are not only created by social entrepreneurs but also are following clear guidelines of "social business" (Ferdousi, 2017). Social businesses are designed and operated like a business to solve major problems of the society, i.e., unemployment, access to healthcare, information, finance, and education, etc. A social business has products, services, customers, markets, expenses, and revenues like a 'regular' enterprise (Yunus et al., 2010). It is a non-dividend company as the investors will get only the invested amount, and businesses have to cover costs and will be self-sustaining (Yunus et al., 2010). For this study, we have taken all the enterprises those who are following the principles of social business developed by Professor Muhammad Yunus. The combination of its economic and social goals including a clear commitment to the seven principles of social business (socialbusinesspedia.com) renders this organisation as a social business.

The social business model is not only expected to create more valued customers but also able to drive workforce productivity and effectiveness through accelerating innovation. For ensuring the growth of a sustainable social business model, scaling up its impacts on its target customers, employees, and investors are highly expected. Although considerable research activities are conducted on the emergence of social ventures (Austin et al. 2006; Mair and Marti, 2006) but the issue of social enterprise growth (Blundel and Lyon, 2015; Hynes, 2009) and its impact on sustainable livelihood ( Ferdousi \& Mahmud, 2018) have attracted limited research attention. As policymakers are increasingly viewing social enterprise as an alternative model to deliver services (Defourny and Nyssens, 2010), there is growing interest in ways to scale up successful social enterprise models (Blundel and Lyon, 2015; Lyon and Fernandez, 2012). Since there is limited research on the specific growth strategies of social ventures (Jenner, 2016) the present study is attempted to outline the range of scaling up strategies 
that are used by several social business partnership ventures initiated by Grameen Telecom Trust (GTT) through their Social Business Learning and Innovation Fund (SBLIF) projects. The research question that has been addressed through this study is "What strategies do social enterprises follow to scaling up the impact on sustainable living? Seven projects under SBLIF have been analyzed in order to know about their scaling-up strategies and what impact each project has created on sustainable living. Finally, the recommendation has been drawn from the learning experiences of each project.

\section{LITERATURE REVIEW}

\section{Organizational Persona}

Businesses are started for many different reasons. Businesses run by different entrepreneurs, have vastly different internal organisational characteristics, and are located in a range of sectors and locations (Wijewardena et al., 2008). Therefore, every organization has a unique personality, and it's not just restricted to what is conventionally thought of as "company culture". Moreover, a social business is a new form of commercial venture that lies somewhere between for-profit and philanthropy (Agafonow, \& Donaldson, 2015). The greatest challenge of social business is investors in social businesses act as philanthropists, thus forgoing dividends (which are instead ploughed back into the business) of social businesses are doomed to remain under-funded (Agafonow, \& Donaldson, 2015). Therefore, there is also a need to understand the characteristics of social businesses; how they are structured, how they behave, and how they are reacting to the trends and events that are currently affecting them. Personas identify the motivations, expectations, and goals of the organization. As argued by Nazarkina, (2013) organizational personas are distinctive organizational types that are used to illustrate the most common business models used by entrepreneurial firms that offer products and services that facilitate sustainable living. The four organizational personas described by Nazarkina (2013) (i.e., Local Integrator, Enthusiastic Innovator, Cross-Sector Collaborator and Branding Guru), differ in terms of the scale of the problem they address (global or local) and the type of solution offered, are given in figure 1. This study used this model of organisational persona developed by Nazarkina (2013) to analyze the characteristics of social business projects.

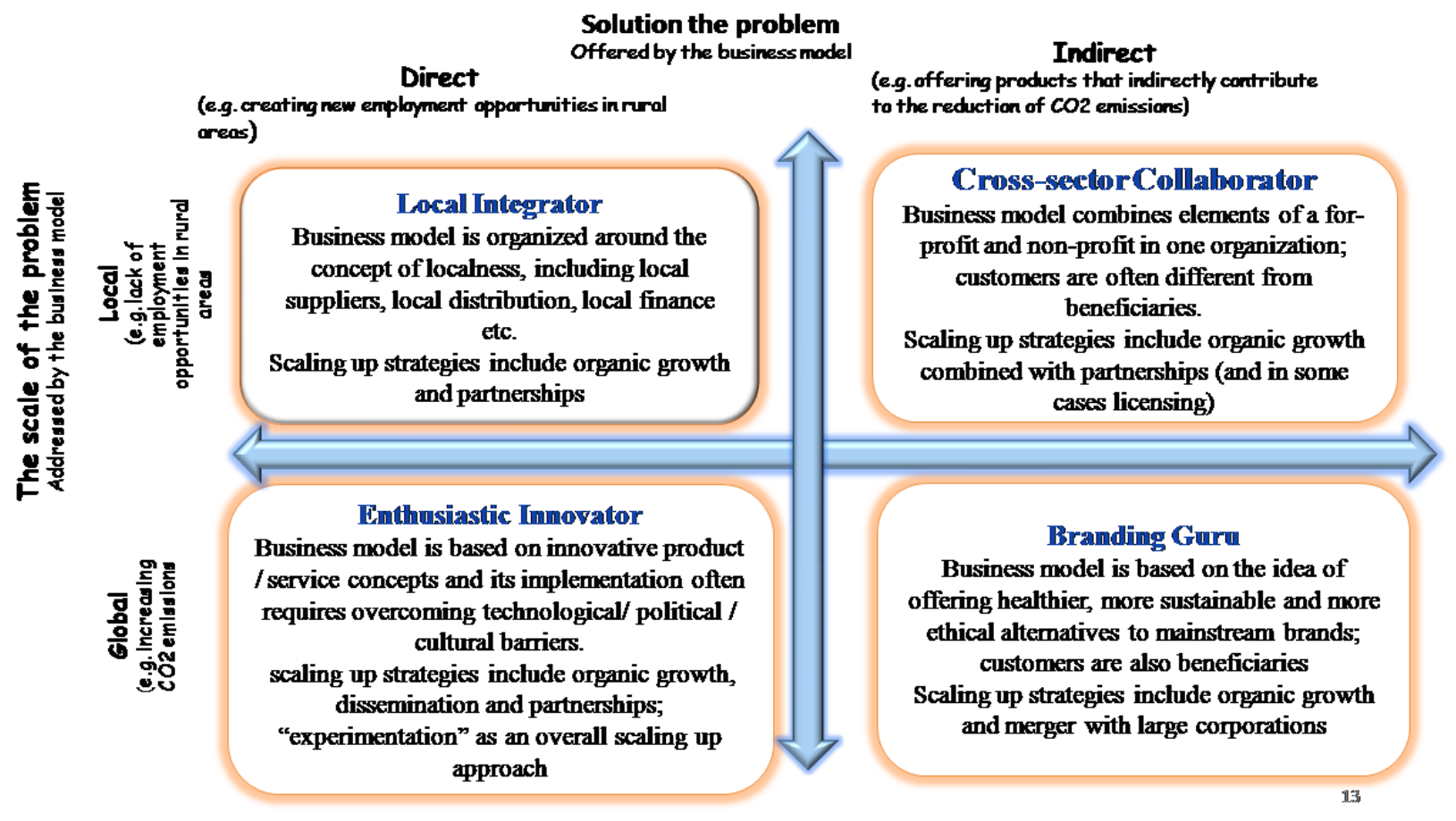

Figure 1: Organizational Personas

Source: Adopted from Nazarkina, 2013

\section{Scaling Strategy}

The term "scaling up" may convey a different meaning to different organizations. Generally, the term may mean 'increase' or 'enlarge' 'doing more' of something. This 'something' might have a different meaning to a different type of organization. Nazarkina (2013) argued that businesses generally tend to perceive scaling as increasing organizational boundaries (e.g. adding new products, opening more outlets, achieving growth in revenues and margins). In contrast, nonprofit and governmental organisations tend to apply the term "scaling up" to projects and programs (e.g. accessing more geographic 
locations especially remote locations, and increasing the number of project beneficiaries. Thus "Scaling-up" might be defined as the process of reaching larger numbers of a target audience in a broader geographic area by institutionalizing effective programs. This study uses the term from the context of SBLIF entrepreneurial projects and is defined as increasing positive business impacts on sustainable living.

Various academic researches explored and made use of several scaling-up strategies. For example; Gabriel (2014) explored four scaling routes which go through 16 activities to spread social innovation such as (1) influence and advice (activities include public speaking, publishing, engaging with policymakers, communicating via traditional and social media, advising or training others); (2) build a delivery network (activities include representation, advocacy, and awareness-raising, transferring knowledge, codifying processes, sharing good practices, providing tools, training support and quality assurance, community, and movement building); (3) form strategic partnership (activities include brokering and managing partnerships with other organizations that allow a step-change in scale, transferring knowledge, creating a sense of common values and mission); (4) grow an organization to deliver (activities include building staff and team capabilities, raising funds/ investments, developing organizational capacity and system). Jenner (2016) proposed five routes for sustainable growth of social ventures such as resourcing, collaborative networks, organizational capabilities, legitimacy, and commercial orientation. Some have considered the potential of franchising, diversification, acquiring, and leveraging as strategies for social enterprise development (Lyon and Fernandez, 2012; Haugh, 2009; Hines, 2005). Many researchers viewed collaborative relationships such as alliances, partnerships or networks as important growth opportunities for social enterprises (Brunetto and Farr-Wharton, 2007; Martinez and Aldrich, 2011; Davidsson et al., 2010; Hansen and Hamilton, 2011; Dobbs and Hamilton, 2006). Lyon and Fernandez (2012), classified scaling up strategies as follows; growth in social impact, scaling through formalised relationships with other providers, open-source sharing, and disseminating good practice.

Nazarkina (2013) explained six scaling strategies from three dimensions (scaling impacts by growing the organization, scaling impact by growing beyond the organization, and scaling impacts by reducing organizational boundaries). This study mainly investigates scaling strategies similar with Nazarkina (2013). Among the six strategies provided by the abovementioned author, this study found evidence of three strategies within the selected case studies. These are given in figure 2.

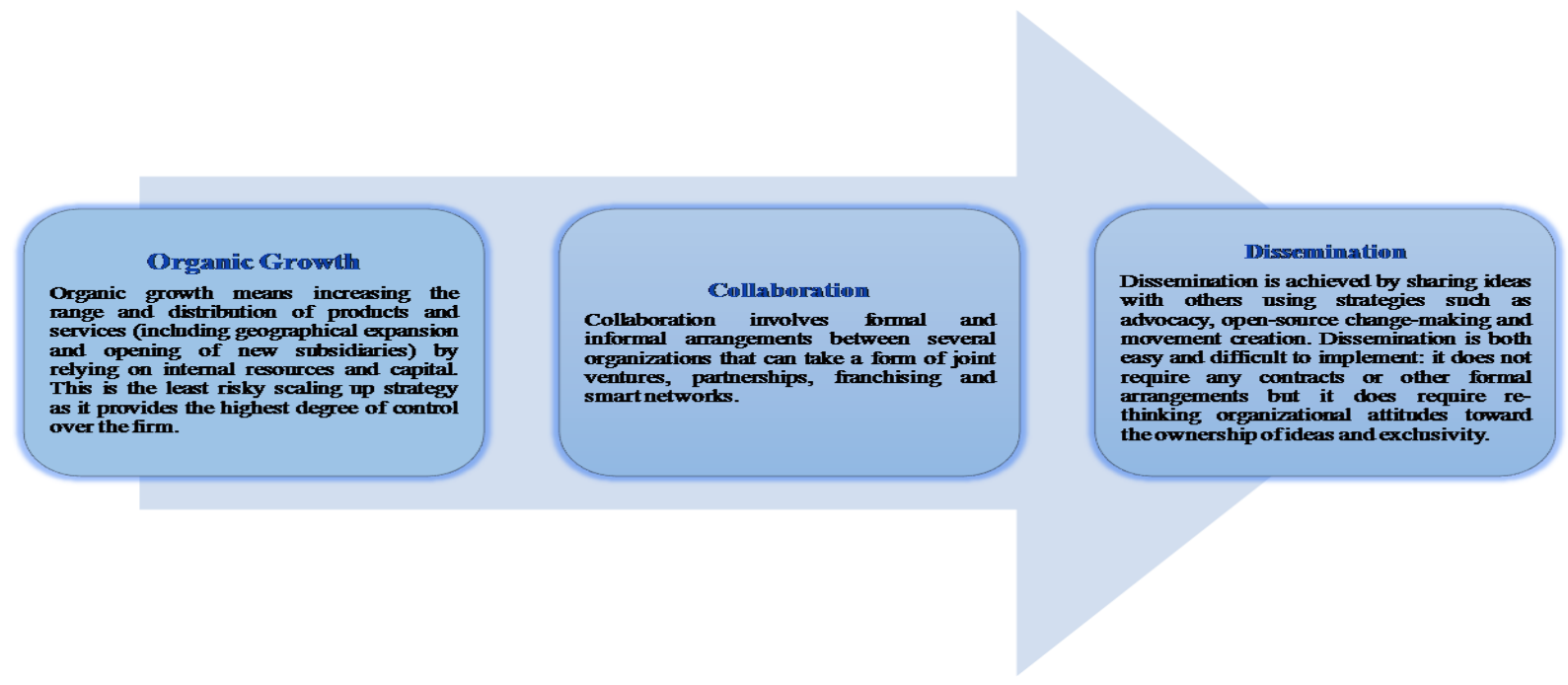

Figure 2: Scaling Up Strategies

Source: Adopted from Nazarkina, 2013

\section{Sustainable Living}

Sustainability very often comes to mean the ability to meet present needs without damaging or depleting the environmental, economic, or social resources that future generations will need. Thus, sustainable living can be defined as patterns of consumption and production that enable present generations to achieve healthy and happy lives while respecting environmental limits and thus enabling future generations to enjoy the same opportunities (Abdullah et al., 2012). A livelihood "incorporates the capabilities, assets [...] and activities required for a means of living. A livelihood is sustainable when it can withstand stresses and shocks, maintains or increases its capabilities and assets, without undermining the natural resource base" (Scoones, 1998, p. 5; Serrat, 2017). "Sustainability refers to reducing poverty by empowering the poor to build on their opportunities". Social enterprises are well-acknowledged for creating a positive socio-economic impact on the 
community (Doherty et al., 2009; Galera and Borzaga, 2009). For example, Grameen Danone is producing yogurt to reduce malnutrition from rural poor children (Ghalib \& Hossain, 2008; Sardana, 2013; Agnew \& Henson, 2018; Peerally et al., 2019), Grameen Veolia is providing safe drinking water in arsenic prone areas in order to reduce arsenic-related disease, Grameen GC Eye Care hospital is providing affordable eye care services for rural poor (Ferdousi, 2017), Grameen Caledonean College of Nursing is providing nursing education for underprivileged girls (Parffit \& Nahar, 2016; Ferdousi, 2017), Grameen Shakti is providing clean energy solution (Hackett, 2016) and Grameen Bank is providing microcredit to poor people for self-employment or increasing income (Ferdousi, 2015; Ferdousi, et al., 2012).

This study makes use of 8 sustainable living principles that have been developed by UNESCO to conduct research activity in the Annapurna region in Nepal (UNESCO, 2000).

These are shown in figure 3.

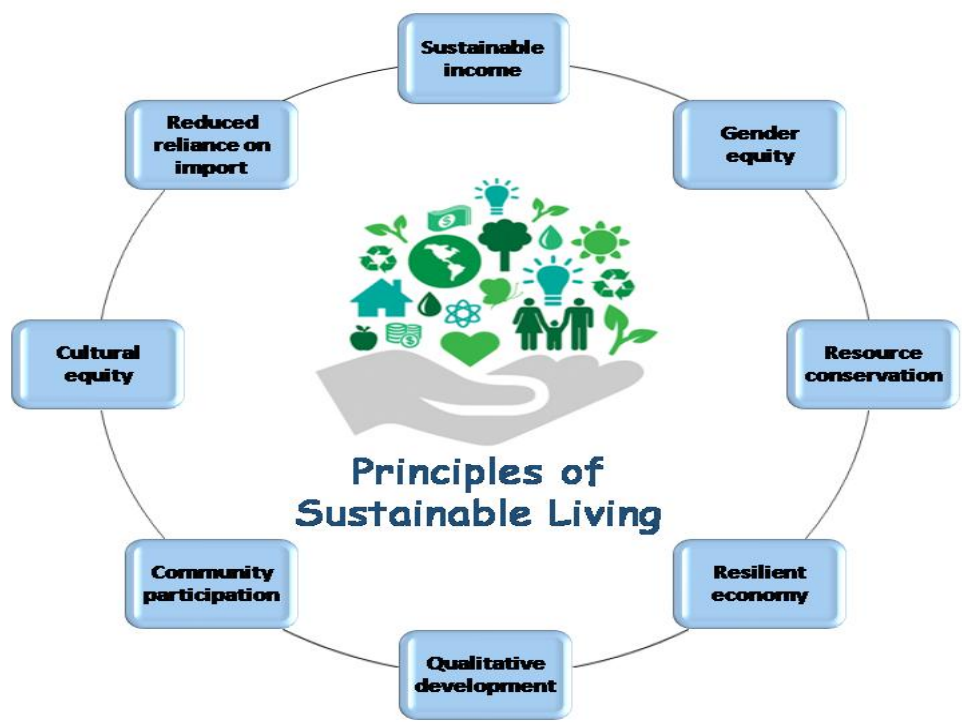

Figure 3: Principles of Sustainable Living

Source: Adopted from UNESCO, 2000

Based on the above-mentioned literature following conceptual model (figure 4) has been developed and adopted for this study.

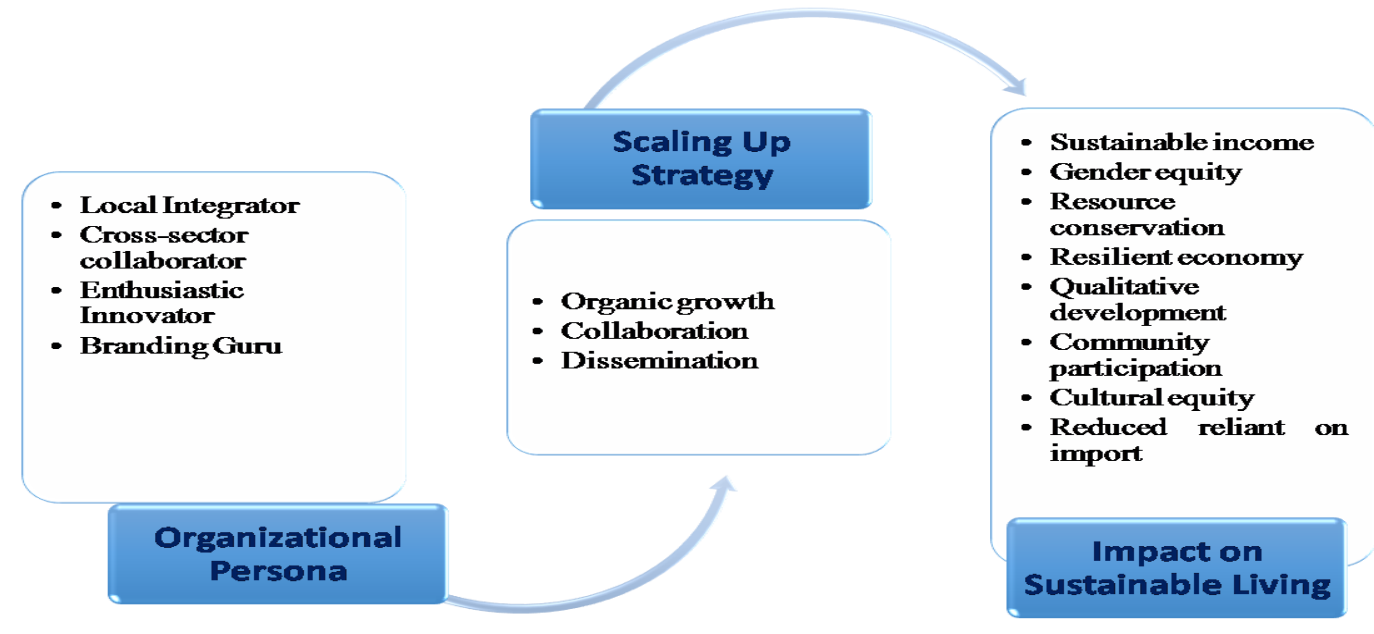

Figure 4: Conceptual Framework

Source: Authors' compilation based on Literature Review 


\section{METHODOLOGY}

\section{Research Design}

The nature of the research question and the need to explore different business strategies for a sustainable impact on livelihood requires a qualitative approach. Social business organizations are not numerous in Bangladesh because of some distinct features and specific principles. Therefore, collecting data from a large sample size to conduct a quantitative study was not possible. Therefore, an exploratory case study approach was found suitable for this study because case studies are used to develop theories and/or generate new insights and knowledge about contemporary phenomena within real-life contexts (Yin, 2003:13).

\section{Population and sample of the Study}

This study considered Social Business Learning and Innovation Fund (SBLIF) projects as the population which is supervised and funded by the Grameen Telecom Trust (GTT). SBLIF is running 11 projects among them we have selected 7 projects. The samples were selected purposively mostly based on the project life. SBLIF started funding social business projects from 2013. We have excluded 4 relatively new projects, whose operations are slightly more than 1 year. Among the sample projects, 3 projects already reached their break-even, and the rest 4 yet to reach break-even.

\section{Data collection procedure}

Triangulation was required for this study to ensure the reliability and validity of the research methodology by using various sources (informants) of data collection and various methods of data collection (interviews, field observations, documents) (Altinay \& Paraskevas, 2008; Altinay, et al., 2016).

The study has made use of all required secondary sources of data that are available through GTT's websites as well as their internal official documents. To analyze the potential social and economic impact of the projects the study also conducted a face-to-face interview with each of the selected project managers. Each of the interviews was recorded and rest on an average of 45 minutes or more. Besides this, one senior executive related to the SBLIF project was also interviewed to understand the management and operational mechanisms of the projects. Thus eight key informant interviews were conducted to know about the business model of SBLIF and seven sample projects under SBLIF. From the supply side, respondents were asked to describe their business model, key strategies, social missions, and impact on target beneficiaries. From the demand side, 14 interviews, two from each project, were conducted on project beneficiaries to understand the livelihood impact. Each of the interviews rested from 30 to 45 minutes which were recorded and then transcribed. The respondents were selected conveniently based on their availability.

In addition, a variety of documents were accessed such as news articles in the "Nobin" published by GTT and respective websites of each project and reports and records from socialbusinesspedia.com These gave insights into the declared mission of each social business project, the nature of activities undertaken to achieve it, and the recognized successes (Altinay et al., 2016). Furthermore, the researchers were given extensive tours around the study villages and projects and interacted with staff members, and residents (Altinay et al., 2016). Moreover, since the inception of the SBLIF, both of the authors are closely working, monitoring, and observing the progress of the projects. The case study material was complemented by a review of the literature regarding growth, scaling up and social franchising strategy that has been developed elsewhere (Lyon, \& Fernandez, 2012).

\section{Analysis Technique}

The collected data were analyzed and congregated in the form of cases. Each interview was imported as a case in order to acknowledge contributions from all informants and transcripts were saved with code names that could be recognized (Altinay et al., 2016). The study mainly investigated seven case studies from SBLIF projects. Exploring organizational characteristics, scaling up strategies and sustainable impacts on beneficiaries were the objectives of this research. Therefore, descriptive research findings are provided case wise.

\section{RESULT AND DISCUSSION}

\section{Grameen Telecom Trust (GTT)}

Grameen Telecom Trust (GTT) is one of the prominent social business companies (Ferdousi \& Mahmud, 2019), started its operation in 2010 under the Trust Act. GTT is the flagship entity (Ferdousi \& Mahmud, 2018) responsible for implementing and facilitating Social Business ideas. It strives to transform societies through social business. When innovative ideas related to a particular field are delineated, GTT designs them as prototypes for sustainable replication. Thus GTT envisions reducing poverty from the world through sustainable social business models. 


\section{Social Business Learning and Innovation Fund (SBLIF)}

The Social Business Learning and Innovation Fund (SBLIF) has been formed to encourage innovative enterprises to adopt social business models. GTT has pioneered SBLIF to innovate, incubate, and translate new ideas into action (Ferdousi \& Mahmud, 2018). The objective of SBLIF is to facilitate social businesses through learning by doing and implement them on a pilot basis. Successful and tested models can gradually be scaled up and replicated. The proposed modes of funding these social businesses include project financing, equity financing, working capital financing, joint venture or 100\% Grameen Telecom Trust (GTT) ownership, etc. GTT considers those enterprises as innovative which take creative steps in benefiting its clients, with a social objective of broadening opportunities, for instance, through ensuring wage employment, employing disadvantaged people, increasing income, offering affordable products and services, providing fair prices, and facilitating income through training \& learning opportunities. Thus following social business principles these enterprises are expected to improve the socio-economic condition of the target clients as a whole. Brief descriptions of the SBLIF projects along with their partnership, investment, tenure, and profitability status are given in table 1 . The overall impact of the projects in terms of social mission and employment status are given in table 2 .

Table 1: Overview of the selected projects

\begin{tabular}{|c|c|c|c|c|c|c|}
\hline $\mathbf{S N}$ & $\begin{array}{l}\text { Project Name/ } \\
\text { Location }\end{array}$ & $\begin{array}{c}\text { In } \\
\text { Operation } \\
\text { Since }\end{array}$ & Partner & Project Value & $\begin{array}{c}\text { Years in } \\
\text { operation }\end{array}$ & Status \\
\hline 1 & $\begin{array}{l}\text { SDRS Handicraft } \\
\text { Social Business } \\
\text { (Giabandha) }\end{array}$ & Dec 2013 & SDRS \& GTT joint venture Project & $\begin{array}{l}\text { BDT } 83,81,500 \\
\text { (USD 1,07,455) }\end{array}$ & 3.6 years & Profitable \\
\hline 2 & $\begin{array}{l}\text { SDRS Solar Social } \\
\text { Business } \\
\text { (Giabandha) }\end{array}$ & Jan 2015 & SDRS \& GTT joint venture Project & $\begin{array}{l}\text { BDT } \quad 89,40,200 \\
\text { (USD 1,14,617) }\end{array}$ & 2.5 years & $\begin{array}{l}\text { Yet to be } \\
\text { breakeven }\end{array}$ \\
\hline 3 & $\begin{array}{l}\text { SKS Social } \\
\text { Business } \\
\text { (Giabandha) }\end{array}$ & Aug 2013 & SKS \& GTT joint venture Project & BDT $30,00,000$ & 3.10 years & $\begin{array}{l}\text { Yet to be } \\
\text { breakeven }\end{array}$ \\
\hline 4 & $\begin{array}{l}\text { Aroni Social } \\
\text { Business } \\
\text { (Thakurgaon) }\end{array}$ & Jul 2014 & ESDO \& GTT joint venture Project & $\begin{array}{l}\text { BDT21, } 71,740 \\
\text { (USD 27, 842) }\end{array}$ & 3 years & Profitable \\
\hline 5 & $\begin{array}{l}\text { Mobile Nursery } \\
\text { Plant Clinic } \\
\text { (Dhaka) }\end{array}$ & Jun 2014 & $\begin{array}{l}\text { Green Savers \& GTT joint venture } \\
\text { Project }\end{array}$ & $\begin{array}{l}\text { BDT } 14,00,000 \\
\text { (USD 17,948) }\end{array}$ & 3 years & $\begin{array}{l}\text { Yet to be } \\
\text { breakeven }\end{array}$ \\
\hline 6 & $\begin{array}{l}\text { Mushroom Seed } \\
\text { Social Business } \\
\text { (Rangamati) }\end{array}$ & Nov 2014 & $\begin{array}{l}\text { AshikaManobikUnnayon Kendra\& } \\
\text { GTT joint venture Project }\end{array}$ & $\begin{array}{l}\text { BDT27,05,000 } \\
\text { (USD 34,679) }\end{array}$ & 2.6 years & $\begin{array}{l}\text { Yet to be } \\
\text { breakeven }\end{array}$ \\
\hline 7 & $\begin{array}{l}\text { Niamatpur Sweets } \\
\text { Ltd. } \\
\text { (Naogaon) }\end{array}$ & Jan 2015 & $\begin{array}{l}\text { LUSTRE \& GTT joint venture } \\
\text { Project }\end{array}$ & $\begin{array}{l}\text { BDT 12,50,00 (USD } \\
16,025)\end{array}$ & 2.5 years & Profitable \\
\hline
\end{tabular}

Source: Grameen Telecom Trust ( 2017)

Table 2: Employment overview of the selected projects

\begin{tabular}{|c|c|c|c|c|c|c|}
\hline SN & Project Name & Social Objectives & $\begin{array}{l}\text { No of full } \\
\text { time } \\
\text { employees }\end{array}$ & Male & Female & Part-time \\
\hline 1 & $\begin{array}{l}\text { SDRS Handicraft } \\
\text { Social Business }\end{array}$ & $\begin{array}{l}\text { Crafting livelihood of rural women } \\
\text { through handicrafts }\end{array}$ & 7 & 2 & 5 & $\begin{array}{l}\text { Male }=2 \\
\text { Female }=890\end{array}$ \\
\hline 2 & $\begin{array}{c}\text { SDRS Solar Social } \\
\text { Business }\end{array}$ & $\begin{array}{l}\text { Advocating green energy through } \\
\text { female producers. The profit } \\
\text { generated shall be invested in digital } \\
\text { school for under privileged children }\end{array}$ & 31 & 8 & 23 & $\begin{array}{l}\text { Male }=8 \\
\text { Female }=0\end{array}$ \\
\hline
\end{tabular}




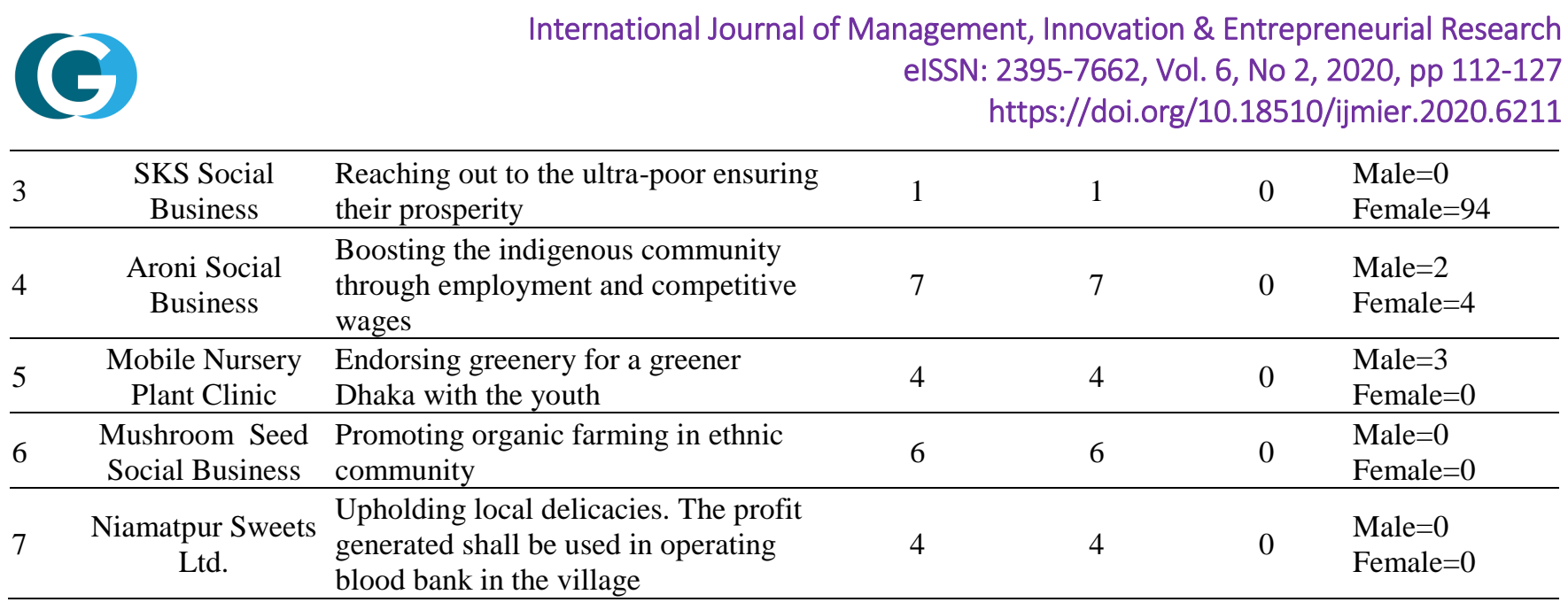

Source: Grameen Telecom Trust (2017)

\section{Description of the case}

\section{SDRS Handicrafts Social Business}

SDRS is the first social business project in Bangladesh launched by Grameen Telecom Trust (GTT) under the Social Business Learning and Innovation Fund (SBLIF). 'SDRS Social Business Project' is based at Gaibandha district and implemented by SDRS, an NGO. The project focuses on increasing the income of rural households mostly living in the chars (isolated river islands) by ensuring that rural women producers get the 'best price' from their produced items either from establishing local market linkage or from exports. The project has created an opportunity for 250 producers to sell their product either in the local and international market through ensuring fair prices. The project is scaling up through creating additional 250 producers in the existing network by providing training to produce handicrafts items such as nokshi kantha, bed sheet, saree, salwar kameez, and kurta sets, etc. The potential impact of this project on ensuring market linkages that creates sustainable income-generating opportunities for women. The women are pursuing their academics and supporting their studies through the earnings of this program.

\section{SDRS Solar Social Business}

SDRS Solar Project is another social business project by Grameen Telecom Trust (GTT) under the Social Business Learning and Innovation Fund (SBLIF). The main focus of this business is to promote the social \& economic advancement of ultrapoor people through generating employment in the community. SDRS operates through assembling solar power generation related instruments and promoting green energy. Also, the profit from this project will assist fifty (50) children to receive computerized digital education. The special feature of this project is that they are empowering women through employing them in the production of green technologies. Thus, the project will not only produce green energy for a healthy environment but also promote equal opportunity for women in the community.

\section{Oroni Social Business}

This is a joint project with the Eco-Social Development Organization (ESDO) which was initiated from Thakurgaon. This social business focuses on producing and supplying pure mustard oil throughout Bangladesh. The business engages more than 1000 indigenous farmers who have been paid the best price for their mustard seed production. Local production and distribution of mustard oil will facilitate local producers to enjoy higher income potentials.

\section{Green Savers Social Business}

Green Savers is an eco-friendly organization that has taken pragmatic steps to inspire and involve citizens to create gardens in their respective households. The vision is to motivate people to plant trees that will promote greenery and provide fresh produce. They are pursuing various innovative and motivating techniques to create gardening habits among urban people. For example, an entrepreneur from the Green Savers project told that :

"We have created 'Oxygen box' in several schools where children are expected to save the portion of their tiffin money which will then buy trees to plant in their school premises." 
He also added that

"Green savers also provide plant holder to garment employees for making paint on those plant holder which will then be kept in their working premise for gardening. In this way, green savers create a feeling of ownership among people in making some contribution towards urban greenery."

Green savers also provide training and agriculture extension services among their clients so that they could be able to nurse their plants. Their mobile plant nursery and clinic is an environmental awareness creating initiative.

\section{Niamatpur Sweets Limited}

A joint venture between GTT and LUSTRE strives to empower poor farmers and ethnic minorities through establishing a business that will produce quality sweets and yogurt that is sold in the local market in Niamatpor, Naogaon. Local farmers most of the time struggle to ensure a fair price and consistent sales of their products. The focus of this social business is, therefore, to facilitate poor farmers through purchasing their dairy regularly at the best prices. Additionally, the local markets will also benefit from higher quality products that are created with the highest standards of hygiene and nutrition. The project is expected to address local socioeconomic problems through promoting employment opportunities, providing scope of empowerment for the village community, and developing their rural livelihood.

\section{SKS Social Business}

SKS Social Business Project' started sheep rearing in the district of Gaibandha in order to generate income for the ultra-poor. This project, till now has been in the implementation phase of distributing cows to the households. As the project faced many hurdles mainly due to the prevalence of prolonged flood in Gaibandha lasting for 3 months, thus, contaminating the grass and water of the area and eventually causing drastic death and abortion of the majority of the sheep. Then the project has taken diversification strategies to maintain its growth. The diversification leads to 'SKS Cow Fattening Social Business' which aims to provide healthier and organic beef to the market.

One of the participants shared her experience in the following way:

"We are rearing cows for seven years but we could see profit rarely. But during one year after having training from SKS on organic cow fattening, we have earned more than our expected profit. This improved knowledge and increased profit helped us to increase investment in my husband's business and purchase a small piece of land and repair my house".

\section{ASHIKA Mushroom Seeds Social Business}

The project aims to locally produce and supply organic mushroom seeds/spawns throughout the Hill Tracts of Chittagong (CHT) and also other parts of Bangladesh. The project was undertaken to help the poor farmers and ultra-poor people in the community to generate income through cultivating mushrooms.

\section{Scaling Up Strategies \\ Organic Growth Strategies}

Nazarkina (2013) defined organic growth as increasing the range and distribution of products and services (including geographical expansion and opening new subsidiaries) by relying on internal resources and capital. Lyon and Fernandez (2012) focus on increasing social impact through ensuring maximum benefits to the communities they serve. Organic growth is usually associated with genuine job creation (Pasanen, 2007). Lockett et al. (2011) also described organic growth as the internal generation of resources, e.g. by employing and training new staff. Researchers have frequently examined eleven constructs across disciplines as antecedents of organic growth: (i) innovation, (ii) marketing orientation (iii) advertising (iv) inter-organizational networks, (v) entrepreneurial orientation, (vi) management capacity, (vii) firm age, (viii) firm size, (ix) competition, (x) munificence, and (xi) dynamism (Bahadir et al., 2009).

Analysis of SDRS handicraft social business projects showed that local unemployed and disadvantaged rural women are increasingly employed to scale up production. They are also increasing the number of producers by utilizing the existing network through providing training in designing various handicraft products. They are also facilitating them through accessing local and international marketing networks. The producer can sell their products through Grameen Check (outlets) and Poshra (online platform). GTT is also introducing those products through their international networks, i.e. import, international fair and Global Social Business Summit. 
SDRS solar social business is also promoting employment through providing technical training skills to women. This diversified skill training could reduce the poor women's vulnerability. Thus SDRS is not only uplifting the income of ultrapoor women but also protecting the environment through providing renewable energy resources.

One of the beneficiaries of the project expresses her feelings in the following ways-

"Training that I have received from SDRS, not only make me confident in my career but also helps me to contribute for the family members"

The organic growth strategy is also followed by Orni social business project. The project is making use of local producers by giving them better and certain prices of their mustard seeds. Thus they are creating social impact through serving local people with enhanced income opportunities.

Green savers are making the best use of internal resources by providing gardening services at clients' door steps.

Nazmul Haque, a businessman, who came from abroad and got frustrated about seeing concrete made buildings only in Dhaka city without having adequate greenery, was inspired to get started with rooftop gardening with the help of Green Savers.

In addition to expressing his gratitude toward Green savers, Nazmul invited his neighbors and relatives also to make a garden to provide fresh fruits, vegetables, and flowers with fresh air for the family members.

Organic growth strategies are also followed by Niamatpur Sweets social business through utilizing the available local resources and providing increased income opportunity to local producers through the purchase of dairy-related inputs.

Anwar a local producer of milk was saying that:

"Previously I have to sell my dairy milk to a remote market place, now all of my produced milk is purchased by Niamatpur sweets which not only reduced my transportation cost but also minimize the loss due to unsold milk. Now I am getting almost fixed income through the selling of milk with better price".

SKS social business project is also following organic growth strategies through continuously increasing its distribution of cows. The project has also taken several diversified strategies to keep its growth momentum sustainable.

Organic growth strategies are also prevalent in ASHIKA Mashroom Seeds' social business project which is addressing local needs. The project is increasing its product distribution through organic and healthy production of mushroom seeds. Ashim Chakma, a local mushroom producer in Rangamati said:

"During the pick season generally from February - April there are huge demands for mushroom seeds. Generally, we depend on ASHIKA for seeds but the inadequate production capacity of ASHIKA compelled us to contact several sellers from Dhaka for collecting seeds. Sometimes we also offer some bribe to collect the seeds"

Many small producers like Ashim are reliant on ASHIKA for collecting their required seeds. Therefore, the project has enormous growth potentials by serving an increased number of local producers.

\section{Collaboration Strategies}

Collaboration involves formal and informal arrangements between several organizations that can take the form of joint ventures, partnerships, franchising, and smart networks (Nazarkina, 2013). Focusing on the need for collaboration, Altinay et al. (2016) demonstrated that social enterprise faces difficulties in accessing resources necessary for social value creation and the need to get different stakeholders involved in the process of social enterprise. Collaboration strategies enable organisations to manage risk, promote innovation (Pfeffer, 2003; Ahuja, 2000), share information (Pfeffer and Salancik, 1978), reduce operational costs (Williamson, 1985; Dyer, 1997), access and create new resources (Dyer and Singh, 1998), all of which are said to provide competitive advantages especially to the smaller organizations (Barnir and Smith, 2002; Dyer and Singh, 1998; Child and Faulkner, 1998). Collaboration also brings some challenges from the perspectives of differences and asymmetry between the organizations in terms of governance structure, mission, culture, and staff, etc (Huybrechts \& 
Nicholls, 2013). However, this assumption of differences and asymmetry might also bring complementary dynamics and efficiency prospects that favors Collaboration (uybrechts \& Nicholls, 2013).

All the SBLIF projects were the outcome of joint collaboration with GTT. Partnership with GTT facilitates SBLIF enterprises through business model sharing and learning opportunities. For example, the local producers in collaboration with SDRS are getting a chance of accessing an improved network, increasing sales, and generating income. SDRS partnership with GTT is not only ensuring the availability of seed funds but also allowing access to several other Grameen companies whose network crosses the national boundaries. Therefore, the business could be benefitted in any areas of marketing, financing, and managing technology and growth opportunities by sharing knowledge within the networks.

Orni social business project is a joint effort of GTT and ESDO, a local NGO. ESDO is not only sharing GTT's managerial and financial experiences but also sharing their knowledge with local endogenous farmers who never know when and how to produce better quality mustard seeds.

One of the respondents mentioned that:

"The contact with ESDO partners not only helped us to cultivate more seeds but also reduced our production and transportation costs, as we do not have to collect our seeds, and fertilizers and take our produced seeds in the market for an uncertain, in most cases, low price from the buyers. Moreover, it exempted us from giving taxes to local marketers."

Another joint venture project of GTT and Green Savers is promoting social franchising with various schools, colleges and universities through having formal and informal contacts by organizing seminars on protecting the environment through the green movement.

Neamatpur Sweet project is also the joint effort of GTT and LUSTRE, a local producer. The profit of this project will be invested to build a blood bank to serve the local poor those who are unable to afford access to healthcare services. The collaboration between GTT and SKS, a local NGO, which is jointly working for uplifting rural livelihoods in one of the climate-vulnerable regions of North Bengal.

ASHIKA Manobik Unayon Kendro, a local NGO in collaboration with GTT is producing agro-based mushroom products. The executive director of ASHIKA, told that:

"I did not have enough confidence in running a business previously, because I have no experience in operating a business, facing marketing, financial and managerial challenges, but the collaboration projects gives me adequate confidence for starting up venture and also creates visionary leadership through the social business network. Moreover, many of the business risks could be shared with an experienced partner."

\section{Dissemination strategies}

Dissemination is achieved by sharing ideas with others using strategies such as advocacy, open-source change-making, and movement creation (Nazarkina, 2013). Dissemination does not require any contracts or other formal arrangements but it does require re-thinking organizational attitudes toward the ownership of ideas and exclusivity (Clay \& Paul, 2012). All the partners in SBLIF projects are disseminating their knowledge, skills, and experiences among the producers and customers for ensuring sustainable livelihood among the beneficiaries. For example, SDRS are providing many formal and informal training among the inhabitants to facilitate their self-employment initiatives. Local producers and sellers are not only helping them in improved learning on sustainable business growth but also replicating sustainable livelihood strategies. Many women in SDRS project are using the income for pursuing their education, health check-up, and maintenance of housing.

A Student of 18 years old named Ayesha Siddiqa also got training from SDRS projects. According to her speech

"now I am capable of earning some extra money which mostly is utilized for better / higher education, and supporting my family members".

Cultivators of mustard seeds expressed their satisfaction with Orni social business project in the following ways: 
The local producers mentioned that they produced mustard many times but they never know about the availability of better quality seeds, appropriate uses of fertilizer and suitable date/timing for harvesting the mustard. But after having training from ESDO, now they are able to produce more mustard seeds with a greater degree of confidence.

Green Savers is promoting knowledge on gardening and planting rooftop orchards to ensure more greenery in urban settings in order to fight against climate change effects and also encouraging urban people to secure their own food staffs which will be chemical-free and healthier through gardening in their small premise.

The SKS project is not only providing financial help but also providing know-how in growing livestock through disseminating knowledge on organic cow fattening and protecting animals from different diseases and risks.

ASHIKA is providing training on how to grow chemical-free organic mushroom seeds and educating people on their dietary benefits. ASHIKA has trained more than 600 producers on producing organic mushroom seeds who are currently serving local markets as the market has a huge demand for this locally produced mushroom seeds. But these 600 producers could be given access to the urban market through the social business network.

\section{Case Analysis}

Analysis of organizational persona showed that all the projects of SBLIF have adopted the behavior of local integrator and cross-sector collaborator (Table 3). But to create a large scale impact, especially beyond their own local and organizational boundaries, the organization also requires them to adopt behavior like an enthusiastic innovator and branding guru. Only Green Savers is going in those directions.

Table 3: Organizational Persona

\begin{tabular}{lcccc}
\hline Project Name & Local Integrator & $\begin{array}{l}\text { Cross Sector } \\
\text { Collaborator }\end{array}$ & $\begin{array}{l}\text { Enthusiastic } \\
\text { Innovator }\end{array}$ & Branding Guru \\
\hline SDRS (Handicrafts) & $\checkmark$ & $\checkmark$ & $\checkmark$ & \\
\hline SDRS (Solar) & $\checkmark$ & $\checkmark$ & & \\
\hline SKS & $\checkmark$ & $\checkmark$ & & \\
\hline Aroni & $\checkmark$ & $\checkmark$ & $\checkmark$ & \\
\hline Green Savers & $\checkmark$ & $\checkmark$ & & \\
\hline Mashroom Seeds & $\checkmark$ & $\checkmark$ & & \\
\hline Niamatpur Sweets & $\checkmark$ & $\checkmark$ & & \\
\hline
\end{tabular}

Source: Analysis of the interview

Analysis of scaling up strategies explored that most of the SBLIF projects are pursuing at least organic growth and collaboration strategies which will increase the number of beneficiaries of the projects and collaboration strategies will facilitate the learning about the production process, technical skill, managerial skills of the project leader and employees of above projects (Table 4). Collaborative partnerships and strategic alliances resulting from networks are supposed to provide significant benefits to organizations through sharing critical information, innovation, and resources (De Carolis and Saparito, 2006; Starr and MacMillan, 1990; Das and Teng, 1998). Researchers viewed these relationships and networks as important in social enterprise success (Dacin et al., 2010; Seelos et al. 2011; Shaw and Carter 2007). But dissemination strategies might focus more on learning livelihood strategies. Except SDRS Solar and Neamatpur Sweets, other projects are using dissemination strategies to some extent. They are providing many formal and informal training to the local producers in order to help them learn the production technologies and earn enhanced income that can improve their livelihood strategies.

Finally, the impact on the sustainable living chart showed that social business by principles is creating a positive impact on sustainable living (Table 5). All the projects of SBLIF are meeting the sustainable living criteria as the social business focuses on three zeros: zero poverty, zero unemployment, and zero carbon emissions. Green savers and SDRS Solar projects are focusing on the green environment and renewable energy sources. SDRS Solar is also employing women employees in order to reduce their vulnerability. Newamatpur sweets, Orni Mustard Oil, and ASHIKA Mashroom seeds are emphasizing on the utilization of local resources and helping the local producers with fair prices and improved technologies. 
Disadvantaged ethnic communities are getting priority to participate in Mushroom seeds production. Thus cultural equity and inclusiveness are being emphasized. SDRS handicrafts are encouraging community participation in learning and earning through handicrafts making and selling. They are also helping them to export their products through providing network information. An interview with the managing director of GTT revealed that they are creating a social business cluster in some villages so that they can create a resilient economy through social business networks and reduce shocks from their livelihoods.

Table 4: Scaling up Strategies

\begin{tabular}{lccc}
\hline $\begin{array}{l}\text { Social Business } \\
\text { Project }\end{array}$ & Organic Growth strategies & $\begin{array}{l}\text { Collaboration } \\
\text { (Partnership/Social } \\
\text { franchising) }\end{array}$ & Dissemination Strategies \\
\hline SDRS (Handicrafts) & $\checkmark$ & $\checkmark$ & $\checkmark$ \\
\hline SDRS (Solar) & $\checkmark$ & $\checkmark$ & $\checkmark$ \\
\hline SKS & $\checkmark$ & $\checkmark$ & $\checkmark$ \\
\hline Aroni & $\checkmark$ & $\checkmark$ & $\checkmark$ \\
\hline Green Savers & $\checkmark$ & $\checkmark$ & $\checkmark$ \\
\hline Mashroom Seeds & $\checkmark$ & $\checkmark$ & \\
\hline Niamatpur Sweets & $\checkmark$ & $\checkmark$ & \\
\hline
\end{tabular}

Source: Analysis of the interview

The social business team leader mentioned that "we try to ensure rational use and skillful management of natural resources. In the SKS project, we train our farmers to produce natural feed for the cows to ensure organic cow fattening."

Table 5: Impact on sustainable Living

\begin{tabular}{llllllll}
\hline $\begin{array}{l}\text { Sustainable } \\
\text { Living } \\
\text { Principles }\end{array}$ & $\begin{array}{l}\text { SDRS } \\
\text { (Handicra } \\
\text { fts) }\end{array}$ & $\begin{array}{l}\text { SDRS } \\
\text { (Solar) }\end{array}$ & SKS & Aroni & $\begin{array}{l}\text { Green } \\
\text { Savers }\end{array}$ & $\begin{array}{l}\text { Mushroo } \\
\text { m Seeds }\end{array}$ & $\begin{array}{l}\text { Niamatpur } \\
\text { Sweets }\end{array}$ \\
\hline $\begin{array}{l}\text { Sustainable } \\
\text { income }\end{array}$ & $* * *$ & $* * *$ & $* * *$ & $* * *$ & $* * *$ & $* * *$ & $* * *$ \\
\hline Gender equity & $* * *$ & $* * *$ & $* *$ & $* *$ & $*$ & $*$ & $*$ \\
\hline $\begin{array}{l}\text { Resource } \\
\text { conservation }\end{array}$ & $* * *$ & $* * *$ & $* * *$ & $* * *$ & $* * *$ & $* * *$ & $* * *$ \\
\hline $\begin{array}{l}\text { Resilient } \\
\text { economy }\end{array}$ & $* * *$ & $* * *$ & $* * *$ & $* * *$ & $* * *$ & $* * *$ & $* * *$ \\
\hline $\begin{array}{l}\text { Qualitative } \\
\text { development }\end{array}$ & $* * *$ & $* * *$ & $* * *$ & $* * *$ & $* * *$ & $* * *$ & $* * *$ \\
\hline $\begin{array}{l}\text { Community } \\
\text { participation }\end{array}$ & $* * *$ & $* * *$ & $* * *$ & $* * *$ & $* * *$ & $* * *$ & $* * *$ \\
\hline $\begin{array}{l}\text { Cultural equity } \\
\text { Reduced reliant } \\
\text { on import }\end{array}$ & $* * *$ & $* * *$ & $* * *$ & $* * *$ & $* * *$ & $* * *$ & $* * *$ \\
\hline
\end{tabular}

Source: Analysis of the interview

Note: “***” means strong focus, “**” medium focus, and "*” weak focus

Interviews with the respondents explored that they use their income in education, treatment and betterment of their family members. Thus, any increase in income will lead to the qualitative development of their livelihoods. Therefore, SBLIF projects make their valid claim for meeting sustainable livelihood principles to some extent through their social businesses.

\section{CONCLUSION}

Scaling social enterprises is a very critical concern as most of the social enterprises struggle to maintain financial and operational inadequacy. The growing literature on scaling up strategies although is available for traditional profit-making organizations, limited evidence is available for social enterprise sectors. Therefore, this study contributed to the current 
literature by showing empirical evidence of few social enterprises, their scaling strategies, and the impact of such strategies on sustainable living.

The findings have important implications for both practitioners and policy-makers. Practitioners need to acquire the required efficiency to persistently pursue growth strategies which are very critical for organizational sustainability. This sustainability will also attract potential collaborations which could help their goal achievement more effectively and efficiently. Policymakers also need to create a supportive environment for the potential growth of this sector. The government needs to understand the potential role of this sector and acknowledge them with proper social and organizational legitimacy. The government can also provide an appropriate framework for collaboration among the social enterprise, government, and corporations. Thus, if proper environments are created, social business sectors could deliver an important competitive advantage in the marketplace and uplift the living standard of its beneficiaries, i.e. customers, producers, practitioners, and network members. Therefore, scaling up social business for achieving organizational sustainability as well as the sustainable livelihood of its beneficiaries should be considered with utmost priority. Moreover, the sustainability of these ventures is also influenced by their ability to access and utilize resources, and capabilities to develop organizational networks. Additionally, disseminating sustainable livelihood strategies is also part of their social mission which is also recognized as a panacea for their social legitimacy.

Thus, scaling up strategies utilized by SBLIF projects are very logical to create an impact on sustainable living. But in order to create more impact and awareness among the target beneficiaries, social business leaders should be motivated to become an enthusiastic innovator. More dissemination strategies may also benefit the target beneficiary to undertake more resilient livelihood strategies.

\section{LIMITATION AND STUDY FORWARD}

However, despite this study offering insights into the impact of social business scaling up strategies on sustainable livelihood, its limitations need to be acknowledged. Firstly, the present study only made use of qualitative research techniques. Future research, however, can collect quantitative information on sustainable living criteria. Furthermore, the study only includes data from SBLIF projects, other social business ventures also need to be included. SBLIF project only has collaboration with local partners or producers. Other international collaborations like Grameen Danone, Grameen Intel, Grameen Veloia, etc are not considered in this sample. Future research might include international collaboration projects as well.

\section{ACKNOWLEDGEMENT}

We would like to express deep gratitude to Nobel Laureate Professor Muhammad Yunus for his encouragement, guidance, and direct assistance during the data collection. The authors acknowledge the Managing Director of Grameen Telecom Trust for her contribution in providing necessary logistic support for conducting the survey and allowing access to other necessary information as required. This study will owe to the Yunus Center team members, Jayanta Kumar Basu, K.M. Saleheen, Shikder M. Zafry, and others for their contribution in data collection, data editing, and compilation. This study also remembers the encouragement and support of Lamiya Morshed, Executive director of Yunus Center. We are also grateful to the anonymous reviewers for their constructive comments and the editor for giving us chances to develop it further.

\section{CONFLICT OF INTERESTS}

The authors declare that they have no conflict of interests.

\section{AUTHORS' CONTRIBUTION}

Farhana Ferdousi contributed in drafting the initial study, including literature review, methodology, obtaining data, analyzing the data, and initial interpretation of the results. Parveen Mahmud contributed in the refining the study background, objectives, and in sharpening the study findings. Both authors read and approved the final manuscript.

\section{REFERENCES}

1. Abdallah, S., Michaelson, J., Shah, S., Stoll, L., \& Marks, N. (2012). The Happy Planet Index: 2012 Report. A global index of sustainable well-being, nef.

2. Agafonow, A., \& Donaldson, C. (2015). The economic rationale behind the social business model: A research agenda. Social Business, 5(1), 5-16. DOI: https://doi.org/10.1362/204440815X14267607784721

3. Agnew, J., \& Henson, S. (2018). Business-based strategies for improved nutrition: The case of Grameen Danone Foods. https://doi.org/10.19088/1968-2018.103

4. Ahuja, G. (2000). The duality of collaboration: inducements and opportunities in the formation of interfirm linkages. Strategic Management Journal, 21(3), 317-343. https://doi.org/10.1002/(SICI)10970266(200003)21:3<317::AID-SMJ90>3.0.CO;2-B 
5. Altinay, L., \& Paraskevas, A. (2008). Planning research in hospitality and tourism. Oxford: ButterworthHeinemann. https://doi.org/10.4324/9780080555942

6. Altinay, L., Sigala, M., \& Waligo, V. (2016). Social value creation through tourism enterprise. Tourism Management. 54, 404-417. https://doi.org/10.1016/j.tourman.2015.12.011

7. Austin, J, Stevenson, H \& Wei-Skillern, J. (2006). Social and commercial entrepreneurship: Same, different or both? Entrepreneurship Theory and Practice, 30(1),1-22. https://doi.org/10.1111/j.1540-6520.2006.00107.x

8. Bahadir, S. C., Bharadwaj, S., \& Parzen, M. (2009). A meta-analysis of the determinants of organic sales growth. International Journal of Research in Marketing, 26(4), 263-275. https://doi.org/10.1016/j.ijresmar.2009.06.003

9. Barnir, A. \& Smith, K.A. (2002). Interfirm alliances in the small business: the role of social networks. Journal of Small Business Management, 40(3), 219-232. https://doi.org/10.1111/1540-627X.00052

10. Blundel, R \& Lyon, F. (2015). Towards a long view: Historical perspectives on the scaling and replication of social ventures. Journal of Social Entrepreneurship, 6(1), 80-102. https://doi.org/10.1080/19420676.2014.954258

11. Borzaga, C. \& Defourny, J. (2001). The Emergence of Social Enterprise. Routledge, London. https://doi.org/10.4324/9780203164679

12. Brunetto, Y \& Farr-Wharton, R. (2007) 'The Moderating Role of Trust in SME Owner/Managers Decision-Making about Collaboration. Journal of Small Business Management, 45(3),362-87. https://doi.org/10.1111/j.1540627X.2007.00218.X

13. Child, J. \& Faulkner, D. (1998). Strategies of Co-operation. Managing Alliances, Networks, and Joint Ventures. Oxford University Press, Oxford.

14. Clay, A. \& Paul, R. (2012). Open innovation: A muse for scaling. Stanford Social Innovation Review, 17-18.

15. Dacin, P.A., Dacin, M.T., and Matear, M. (2010). Social entrepreneurship: Why we don't need a new theory and how we move forward from here. Academy of Management Perspectives, 24, 37-57. https://doi.org/10.5465/amp.24.3.37

16. Das, T. \& Teng, B. (1998). Between trust and control: Developing confidence in partner cooperation in alliances', Academy of Management Review, 23(3), 491-512. https://doi.org/10.5465/amr.1998.926623

17. Davidsson, P., Achtenhagen, L., \& Naldi, L. (2010). Small Firm Growth. Foundations and Trends in Entrepreneurship, 6(2), 69-166. https://doi.org/10.1561/0300000029

18. De Carolis, D., \& Saparito, P. (2006). Social Capital, Cognition, and Entrepreneurial Opportunities: A Theoretical Framework. Entrepreneurship Theory and Practice, 30(1), 41-56. https://doi.org/10.1111/j.15406520.2006.00109.x

19. Defourny, J. \& Nyssens, M. (2006). Defining social enterprise. In Nyssens, M. (Ed.), Social Enterprise. At the Crossroads of Market, Public Policies and Civil Society. Routledge, London.

20. Defourny, J. \& Nyssens, M. (2010). Conceptions of social enterprise and social entrepreneurship in Europe and the United States: convergences and divergences. Journal of Social Entrepreneurship, 1(1), 32-53. https://doi.org/10.1080/19420670903442053

21. Dobbs, M \& Hamilton, R. (2006). Small business growth: Recent evidence and new directions. International Journal of Entrepreneurial Behaviour and Research, 13 (5), 296-322. https://doi.org/10.1108/13552550710780885

22. Doherty, B, Foster, G., Mason, K., Rotheroe, N. \& Royce, M. (2009). Management for Social Enterprise, Sage, London.

23. Dyer, J.H. \& Singh, H. (1998). The relational view: cooperative strategy and sources of inter organizational competitive advantage. Organization Studies, 23(4),660-679. https://doi.org/10.5465/amr.1998.1255632

24. Dyer, J.H. (1997). Effective interfirm collaboration: How firms minimize transaction costs and maximize transaction value. Strategic Management Journal, 18(7), 535-556.

25. Ferdousi, F. (2015). Impact of microfinance on sustainable entrepreneurship development. Development Studies Research, 2(1),51-63. https://doi.org/10.1080/21665095.2015.1058718

26. Ferdousi, F. (2017). Understanding consumer behavior toward social enterprise products. In Sabah, S. (Ed.), Consumer Behavior-Practice Oriented Perspectives Intech Open. https://doi.org/10.5772/intechopen.68743

27. Ferdousi, F., \& Mahmud, P. (2018). Investment in microenterprises for scaling up business growth: evidence from socialbusiness project. In Mura, L. (Ed.), Entrepreneurship-Development Tendencies and Empirical Approach IntechOpen. https://doi.org/10.5772/intechopen.72126

28. Ferdousi, F., \& Mahmud, P. (2019). Role of social business in women entrepreneurship development in Bangladesh: perspectives from Nobin Udyokta projects of Grameen Telecom Trust. Journal of Global Entrepreneurship Research, 9(1), 58. https://doi.org/10.1186/s40497-019-0184-0

29. Ferdousi, F., Shi Cun, X., \& Mostak, A. G. (2012). Impact of micro-credit loans on income and innovation: evidence from Bangladesh. In Proceedings of the 9th International Conference on Innovation and Management, Eindhoven, TheNetherlands, November (pp. 14-16). 
30. Gabriel, M. (2014). Making it BIG. Strategies for scaling social innovations. Available at: www.nesta.org.uk/publications/making-it-big-strategies-scaling-social-innovations. Accessed on 2 June, 2017.

31. Galera, G \& Borzaga, C (2009). Social enterprise: An international overview of its conceptual evolution and legal implementation. Social Enterprise Journal, 5(3), 210-28. https://doi.org/10.1108/17508610911004313

32. Ghalib, A. K., \& Hossain, F. (2008). Social business enterprises-maximising social benefits or maximising profits? The case of Grameen-Danone Foods Limited. The Case of Grameen-Danone Foods Limited (September 9, 2008). Brooks World Poverty Institute Working Paper, (51). https://doi.org/10.2139/ssrn.1265652

33. Hackett, M. T. (2016). Solving 'social market failures' with social enterprises? Grameen Shakti (Village Energy) in Bangladesh. Journal of Social Entrepreneurship, 7(3), 312-341. https://doi.org/10.1080/19420676.2016.1188324

34. Hansen, B \& Hamilton, R. (2011). Factors distinguishing small firm growers and non-growers. International Small Business Journal, 29(3), 278-94. https://doi.org/10.1177/0266242610381846

35. Haugh, H. (2005). A research agenda for social entrepreneurship. Social Enterprise Journal, 1(1),1-12 https://doi.org/10.1108/17508610580000703

36. Haugh, H. (2009). A Resource-based perspective of social entrepreneurship', in Robinson, J., Mair, J. \& Hockerts, K. (eds.), International Perspectives of Social Entrepreneurship, Palgrave Macmillan, Basingstoke, UK.

37. Hines, F. (2005).Viable social enterprise: An evaluation of business support to social enterprise. Social Enterprise Journal, 1(1),13-28. https://doi.org/10.1108/17508610580000704

38. Huybrechts, B. \& Nicholls, A. (2013). The role of legitimacy in social enterprise-corporate collaboration. Social Enterprise Journal, 9(2), 130 - 146. https://doi.org/10.1108/SEJ-01-2013-0002

39. Hynes, B. (2009). Growing the social enterprise - issues and challenges. Social Enterprise Journal, 5(2), 114-25. https://doi.org/10.1108/17508610910981707

40. Jenner, Peter (2016). Social enterprise sustainability revisited: an international perspective. Social Enterprise Journal, 12(1), 42-60. https://doi.org/10.1108/SEJ-12-2014-0042

41. Lockett, A., Wiklund, J., Davidsson, P., \& Girma, S. (2011). Organic and acquisitive growth: Re-examining, testing and extending Penrose's growth theory. Journal of management studies, 48(1), 48-74. https://doi.org/10.1111/j.1467-6486.2009.00879.x

42. Lyon, F., \& Fernandez, H. (2012). Strategies for scaling up social enterprise: lessons from early years providers. Social Enterprise Journal, 8(1), 63 - 7. https://doi.org/10.1108/17508611211226593

43. Mair, J. \& Martí, I. (2006). Social entrepreneurship research: A source of explanation, prediction, and delight. Journal of World Business, 41(1),36-44. https://doi.org/10.1016/j.jwb.2005.09.002

44. Martinez, M. \& Aldrich, H. (2011). Networking strategies for entrepreneurs: Balancing cohesion and diversity. International Journal of Entrepreneurial Behaviour and Research, 17(1),7-38. https://doi.org/10.1108/13552551111107499

45. Nazarkina, L. (2013). Scaling up Strategies for Entrepreneurial Firms: How to Scale up Business Impacts on Sustainable Living. CSCP, Germany. www.scp-centre.org

46. Parfitt, B., \& Nahar, N. S. (2016). Nursing education in Bangladesh: a social business model. International nursing review, 63(2), 285-291. https://doi.org/10.1111/inr.12243

47. Pasanen, M. (2007). SME growth strategies: organic or non-organic? Journal of Enterprising Culture, 15(04), $317-$ 338. https://doi.org/10.1142/S0218495807000174

48. Peerally, J. A., De Fuentes, C., \& Figueiredo, P. N. (2019). Inclusive innovation and the role of technological capability-building: The social business Grameen Danone Foods Limited in Bangladesh. Long Range Planning, 52(6), 101843. https://doi.org/10.1016/j.lrp.2018.04.005

49. Pfeffer, J. (2003). Introduction to the classic edition, in Pfeffer, J. and Salancik, G. (Eds), The External Control of Organizations: A Resource Dependence Perspective, Stanford University Press, Stanford, CA.

50. Pfeffer, J., and Salancik, G. (1978), The External Control of Organizations: A Resource Dependence Perspective, Harper \& Row, New York, NY.

51. Sardana, G. D. (2013). Social business and Grameen Danone foods limited. Society and Business Review, 8(2), 119133. https://doi.org/10.1108/SBR-01-2013-0002

52. Scoones, I. (1998). Sustainable rural livelihoods: a framework for analysis, IDS Working Paper Nr. 72, Institute for Development Studies (IDS), Sussex.

53. Seelos, C., Mair, J., Battilana, J. \& Dacin, T. (2011). The Embeddedness of Social Entrepreneurship: Understanding Variation across Local Communities. Communities and Organisations, 33(4), 333-63. https://doi.org/10.1108/S0733-558X(2011)0000033013

54. Serrat, O. (2017). The sustainable livelihoods approach. In Knowledge solutions (pp. 21-26). Springer, Singapore. https://doi.org/10.1007/978-981-10-0983-9_5

55. Shaw, E., \& Carter, S. (2007). Social entrepreneurship. Journal of small business and enterprise development, 14(3), 418-434. https://doi.org/10.1142/S1363919698000109 
56. Starr, J. \& MacMillan, I. (1990). Resource co-optation via social contracting; Resource acquisition strategies for new ventures. Strategic Management Journal, 11, 79-92. https://www.jstor.org/stable/2486671

57. UNESCO (2000) World Culture Report, UNESCO Publishing, Paris. http://www.unesco.org/education/tlsf/ mods/theme c/interact/mod10task03g/mod10task03g.htm

58. Wijewardena, H., Nanayakkara, G., and Zoysa, A. (2008). The owner/manager's mentality and the financial performance of SMEs. Journal of Small Business and Enterprise Development,15(1), 50-161. https://doi.org/10.1108/14626000810850892

59. Williamson, O.E. (1985). The Economic Institutions of Capitalism: Firms, Markets, Relational Contracting, The Free Press, New York, NY.

60. www. socialbusinsesspedia.com

61. Yin, R. K. (Ed.). (2003). Case study research: Design and methods (Vol. 5). London: Sage.

62. Yunus, M., Moingeon, B., \& Lehmann-Ortega, L. (2010). Building social business models: Lessons from the Grameen experience. Long range planning, 43(2-3), 308-325. https://doi.org/10.1016/j.lrp.2009.12.005 